Brit. F. vener. Dis. (1970) 46, 441

\title{
Characterization of treponemes by gas chromatography
}

\author{
D. C. FARSHY, M. L. THOMAS, AND C. W. MOSS \\ From the National Communicable Disease Center, Health Services and Mental Health Administration, Public \\ Health Service, U.S. Department of Health, Education, and Welfare, Atlanta, Georgia 30333, U.S.A.
}

THE control of syphilis is seriously hampered by the lack of a method for in vitro propagation of Treponema pallidum. Recent reports of spiral organisms in the aqueous humour and cerebrospinal fluid of syphilitics (Smith and Israel, 1967; Goldman and Girard, 1968) have stimulated research in the detection and identification of treponemes. However, it is not certain whether the spiral organisms found in body fluids are saprophytic cultivable treponemes or pathogenic $T$. pallidum. Newly-developed laboratory methods for the classification of treponemes may help to clarify this problem.

The sensitive analytical technique of gas-liquid chromatography (GLC) has recently been extended to biological materials. Nonvolatile compounds such as those which occur in cellular material can now be analysed by GLC through preparation of volatile derivatives. The present study reports our investigation of trimethylsilyl (TMS) profiles of whole cell hydrolysates of cultivable treponeme. We have used this technique previously to differentiate certain other bacteria (Farshtchi and Moss, 1969 a,b).

\section{Material and methods \\ ORGANISMS \\ Nine strains of $T$. pallidum (Reiter, English Reiter, Kazan, Kazan 2, 4, 5, and 8, Nichols, and Noguchi), one strain of $T$. refringens, one strain from normal oral flora $(T$. micro- dentium), one strain isolated from California mud ( $T$. zuelzerae), and one Borrelia vincentii strain N-9 were obtained from the Venereal Disease Research Laboratories of the National Communicable Disease Center, Atlanta, Georgia.}

\section{CULTURAL PROCEDURES}

The growth medium employed was identical to that of Hanson and Cannefax (1964) except that the concentration of sodium thioglycolate was reduced from 0.05 to 0.025 per cent. Strains were incubated at $35^{\circ} \mathrm{C}$., except $T$. zuelzerae which was grown at room temperature. After

Received for publication May 6, 1970

Use of trade names is for identification only and does not constitute endorsement by the Public Health Service or by the U.S. Department of Health, Education, and Welfare. the cells were harvested by centrifugation, they were washed several times with decreasing concentration of sodium chloride solutions $(0.85,0.6,0.42,0.2,0.1$, and 0.05 per cent.) to prevent cell lysis. The washed cells were then lyophilized.

\section{SAMPLE PREPARATION}

$20 \mathrm{mg}$. of the dried cells were placed into test tubes fitted with teflon-lined caps. $20 \mathrm{ml}$. of $1 \mathrm{~N} \mathrm{HCl}$ in methanol was added and the cells were hydrolysed for $8 \mathrm{hrs}$ at $100^{\circ} \mathrm{C}$. After cooling, the samples were dried on a rotary evaporator (Buchler Instruments, Fort Lee, N.Y.). The dried samples were re-suspended in methanol and again evaporated. This evaporation procedure was repeated until the hydrolysate was neutral ( $\mathrm{pH} 7 \cdot 0$ ). The dry residue was dissolved in $1 \mathrm{ml}$. dry pyridine (stored over $\mathrm{KOH}$ pellets) and transferred into a stoppered conical glass centrifuge tube. Then $0.3 \mathrm{ml}$. hexamethyldisilazane and $0.15 \mathrm{ml}$. trimethylchlorosilane (Applied Science Laboratories, Inc., State College, Pa.) were added. After shaking for $30 \mathrm{sec}$. the mixture was left overnight at room temperature. The reaction mixture was centrifuged and the supernatant fluid was transferred to another centrifuge tube and evaporated to dryness at $55^{\circ} \mathrm{C}$. under a gentle stream of nitrogen. The residue was dissolved in $10 \mathrm{ml}$. hexane and evaporated to a final volume of $0.25 \mathrm{ml}$. under nitrogen.

GLC ANALYSIS

The samples were analysed with a Barber-Colman Model 5000 Gas Chromatograph (Barber-Colman Co. Rockford, Ill.) equipped with a hydrogen flame ionization detector. Nitrogen was used as carrier gas at an inlet pressure of 24 p.s.i. The column used was an 8 -ft. $(2 \cdot 44 \mathrm{~m}$.) U-tube glass column packed with 3 per cent. OV-1 coated on 60-80 mesh Gas-Chrom Q (Applied Science Labs., Inc., State College, $\mathrm{Pa}$.). The column was temperature programmed from $130^{\circ}$ to $193^{\circ} \mathrm{C}$. $\left(21 \mathrm{~min}\right.$. at a rate of $3^{\circ} \mathrm{C}$. per min. At $193^{\circ} \mathrm{C}$. the rate was changed to $7 \cdot 5^{\circ} \mathrm{C}$. per min. and maintained at this setting until the final temperature of $250^{\circ} \mathrm{C}$. was reached. Detector and injector temperatures were $275^{\circ}$ and $300^{\circ} \mathrm{C}$. respectively. The quantitative data were obtained as described previously (Farshtchi and Moss 1969a).

\section{Results}

The thirteen strains tested were divided into five distinct groups by their characteristic TMS profile (Table, overleaf). 
T A B LE Relative percentages of principal peaks obtained from GLC chromatograms of TMS derivatives prepared from whole-cell hydrolysates of treponemes

\begin{tabular}{|c|c|c|c|c|c|c|c|c|c|c|c|c|c|c|}
\hline \multicolumn{2}{|l|}{ Group } & \multicolumn{7}{|l|}{$I$} & \multicolumn{3}{|l|}{ II } & \multirow{2}{*}{ 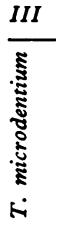 } & \multirow{2}{*}{ 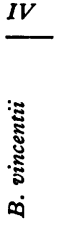 } & \multirow[b]{2}{*}{ 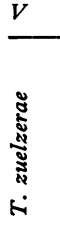 } \\
\hline $\begin{array}{l}\text { Peak } \\
\text { No. }\end{array}$ & $\begin{array}{l}\text { Reten- } \\
\text { tion } \\
\text { time } \\
\text { (min.) }\end{array}$ & 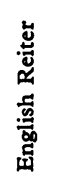 & 岕 & 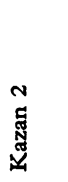 & 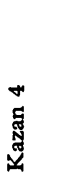 & 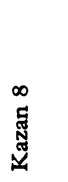 & 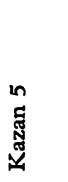 & 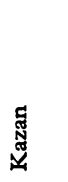 & 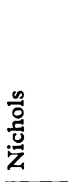 & 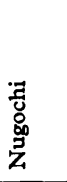 & 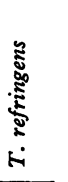 & & & \\
\hline 1 & $11 \cdot 3$ & $9 \cdot 5$ & $9 \cdot 7$ & $9 \cdot 6$ & $10 \cdot 0$ & $10 \cdot 3$ & 8.9 & $9 \cdot 6$ & $1 \cdot 1$ & $1 \cdot 3$ & 1.8 & 0.8 & 1.3 & $7 \cdot 4$ \\
\hline 2 & 13.5 & - & - & - & - & - & - & - & - & - & - & - & - & $2 \cdot 1$ \\
\hline 3 & $14 \cdot 1$ & - & - & - & - & - & - & - & - & - & - & - & - & 1.3 \\
\hline 4 & 14.5 & - & - & - & - & - & - & - & - & - & - & $5 \cdot 4$ & $2 \cdot 8$ & 1.7 \\
\hline 5 & $16 \cdot 2$ & - & - & - & - & - & - & - & - & - & - & $4 \cdot 3$ & $3 \cdot 1$ & $2 \cdot 8$ \\
\hline 6 & $17 \cdot 6$ & - & - & - & - & - & - & - & 1.4 & 0.8 & 1.8 & - & - & - \\
\hline 7 & 17.9 & - & - & - & - & - & - & - & - & - & - & $9 \cdot 4$ & - & - \\
\hline 8 & $18 \cdot 1$ & $2 \cdot 3$ & 3.5 & 2.5 & $4 \cdot 3$ & $5 \cdot 0$ & $3 \cdot 3$ & 3.8 & $4 \cdot 0$ & 3.8 & 3.0 & - & 3.7 & $8 \cdot 3$ \\
\hline 9 & $19 \cdot 1$ & 9.9 & $11 \cdot 6$ & 8.9 & $11 \cdot 0$ & $11 \cdot 6$ & 8.9 & $10 \cdot 4$ & $14 \cdot 2$ & $14 \cdot 4$ & $14 \cdot 7$ & 8.4 & $18 \cdot 4$ & 13.9 \\
\hline 10 & 19.9 & - & - & - & - & - & - & - & - & - & - & 2.5 & - & - \\
\hline 11 & $20 \cdot 2$ & $5 \cdot 0$ & $5 \cdot 3$ & 3.7 & 4.7 & $7 \cdot 0$ & 4.9 & 6.4 & 11.5 & $8 \cdot 5$ & $7 \cdot 2$ & - & $6 \cdot 1$ & 4.9 \\
\hline 12 & $20 \cdot 8$ & $24 \cdot 2$ & $17 \cdot 9$ & 23.4 & $19 \cdot 8$ & $13 \cdot 3$ & $19 \cdot 1$ & $14 \cdot 4$ & $18 \cdot 2$ & $19 \cdot 1$ & $17 \cdot 6$ & $18 \cdot 6$ & $21 \cdot 6$ & $15 \cdot 7$ \\
\hline 13 & $21 \cdot 7$ & $2 \cdot 7$ & $4 \cdot 4$ & 6.4 & $5 \cdot 3$ & 6.7 & $4 \cdot 2$ & $6 \cdot 3$ & $2 \cdot 1$ & 0.8 & 3.4 & $5 \cdot 8$ & $5 \cdot 7$ & 3.8 \\
\hline 14 & $22 \cdot 3$ & $2 \cdot 0$ & 1.8 & $3 \cdot 4$ & 1.3 & 2.5 & 1.9 & 1.9 & $5 \cdot 2$ & $4 \cdot 3$ & $2 \cdot 2$ & 2.9 & $4 \cdot 1$ & 1.9 \\
\hline 15 & 24.9 & 13.7 & $15 \cdot 1$ & $11 \cdot 1$ & $10 \cdot 2$ & $11 \cdot 2$ & $12 \cdot 3$ & 13.0 & $12 \cdot 2$ & $15 \cdot 1$ & $15 \cdot 9$ & $11 \cdot 8$ & 10.9 & 12.9 \\
\hline 16 & 25.5 & $13 \cdot 7$ & 14.0 & $11 \cdot 1$ & $14 \cdot 2$ & $10 \cdot 8$ & 11.5 & $12 \cdot 3$ & $12 \cdot 2$ & 14.0 & $11 \cdot 6$ & $9 \cdot 7$ & $6 \cdot 1$ & 7.5 \\
\hline 17 & $25 \cdot 8$ & - & - & - & - & - & - & - & - & - & - & - & - & $8 \cdot 8$ \\
\hline 18 & $39 \cdot 2$ & 3.8 & $3 \cdot 6$ & 4.0 & 4.9 & 4.0 & $4 \cdot 9$ & $4 \cdot 8$ & $4 \cdot 5$ & $4 \cdot 1$ & 3.8 & $3 \cdot 7$ & - & 0.9 \\
\hline 19 & $40 \cdot 2$ & - & - & - & - & - & - & - & - & - & - & - & - & 1.0 \\
\hline 20 & $41 \cdot 3$ & 0.5 & $T$ & 0.7 & 0.8 & 0.5 & 0.8 & 0.8 & $\mathbf{T}$ & $\mathrm{T}$ & $\mathbf{T}$ & $T$ & - & - \\
\hline 21 & $43 \cdot 2$ & 0.6 & $\mathbf{T}$ & 1.0 & 0.9 & 0.5 & 0.9 & 0.8 & $T$ & $\mathrm{~T}$ & $\mathrm{~T}$ & $T$ & - & - \\
\hline 22 & $45 \cdot 6$ & 1.5 & 1.4 & 1.6 & 1.5 & $1 \cdot 7$ & 1.9 & 1.7 & 1.7 & 1.8 & $2 \cdot 1$ & 1.5 & - & 0.5 \\
\hline 23 & $47 \cdot 7$ & 2.7 & 1.8 & $3 \cdot 4$ & $2 \cdot 2$ & $2 \cdot 3$ & $3 \cdot 2$ & $2 \cdot 1$ & 0.7 & 1.4 & 0.6 & - & - & - \\
\hline 24 & $48 \cdot 6$ & - & - & - & - & - & - & - & & & & - & $\mathbf{T}$ & - \\
\hline 25 & 51.6 & 7.9 & 9.9 & $9 \cdot 2$ & 8.9 & 12.6 & 13.5 & $11 \cdot 7$ & $11 \cdot 0$ & 9.9 & $14 \cdot 3$ & $14 \cdot 7$ & - & 3.3 \\
\hline 26 & 52.9 & - & - & - & - & - & - & - & - & - & - & - & $16 \cdot 2$ & - \\
\hline 27 & $53 \cdot 2$ & - & - & - & - & - & - & - & - & - & - & - & & 1.4 \\
\hline 28 & 53.8 & - & - & - & - & - & - & - & - & - & - & 0.5 & & - \\
\hline
\end{tabular}

The profiles of each group are shown in the Figure (opposite).

Only the percentages of the major peaks and peaks that appeared to have any significance for differentiation were considered in this study (28 peaks). There were seven peaks that were present in all of the organisms $(1,9,12,13,14,15$, and 16). These accounted for 58 to 76 per cent. of all the considered peaks in the various groups (66 to 76 per cent. in group I; 65 to 69 per cent. in group II; 58,62 , and 68 per cent. in groups III, IV, and V, respectively).

The strains which comprised group I were Reiter, English Reiter, Kazan, Kazan 2, Kazan 4, Kazan 5, and Kazan 8. Each of these strains had very similar profiles which could be easily characterized by relatively high percentages of peak $1(8.9$ to 10.3 per cent.). Although T. zuelzerae (Group V) had $7 \cdot 4$ per cent. of peak 1 , it could easily be distinguished from Group I by the presence of peaks 2, 34 , and 5 (Fig. $1 \mathrm{C}$ and $\mathrm{B}$ ).

Group II organisms could be distinguished from Group I by the presence of peak 6, lower percentages of peak 1 , and by slightly higher percentages of peak 9.
Group III could be differentiated from Groups I and II by the presence of peaks $4,5,7,10$, and 28 , and by the absence of peaks 8,11 , and 23 .

Group IV could be separated from Groups I and II by the presence of peaks 4, 5, 24, 26 and by the absence of peaks $18,20,21,22,23$, and 25 ; it could be differentiated from Group III by the presence of peaks $8,11,24,26$ and by the absence of peaks 7,10 , $18,20,21,22$, and 25

Group V could be distinguished from Groups I and II by the presence of peaks $2,3,4,5,17,27$ and by the absence of peaks 20,21 , and 23 Group V differed from Groups III and IV by the presence of peaks $2,3,17$, and 27

Reproducibility of quantitative data and accuracy in determination of retention times have been reported earlier (Farshtchi and Moss, 1969a). The accuracy in determination of retention time in the present study was improved by rigorous control of column cooling time and control of the time interval before injection of the next sample. Variation in retention times was less than $\pm \mathbf{0} \cdot \mathbf{1} \mathrm{min}$. Essentially the same results were obtained with duplicate analyses of lyophilized treponemes. 


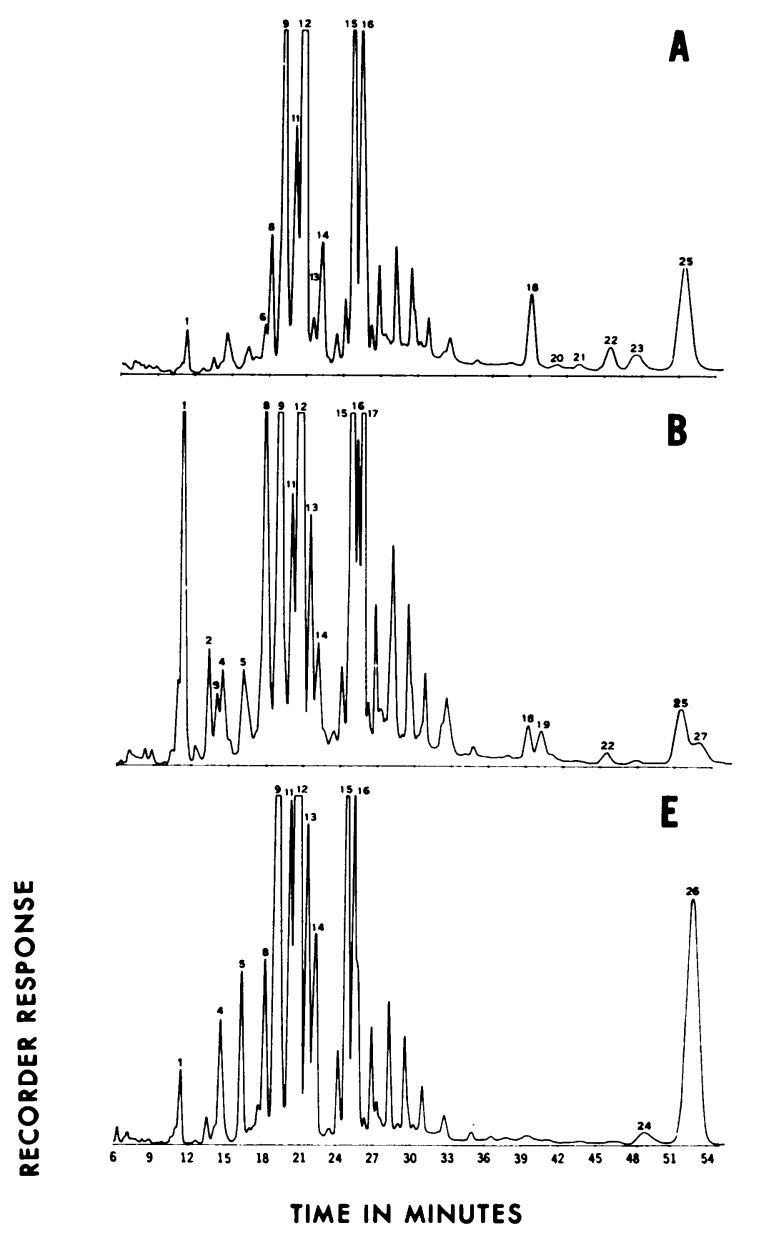

\section{Discussion}

Gas-liquid chromatography is a very sensitive and accurate method for chemical analysis. We have previously studied the fatty acid composition of treponemes by gas chromatography (Cohen, Moss, and Farshtchi, 1970). Recent advances in the formation of derivatives have extended the use of gas chromatography to many compounds present in biological materials. These derivatives are volatile and stable at the temperatures used in GLC. One of the most commonly used derivatives is TMS. With these derivatives it is possible to study mono, di, trisaccharides, and amino sugars by GLC.

The complexity of the TMS profiles of treponemes in this study is due to (a) the presence of many compounds in the hydrolysate, and (b) the formation of more than one peak for each compound. As reported in our earlier work (Farshtchi and Moss,

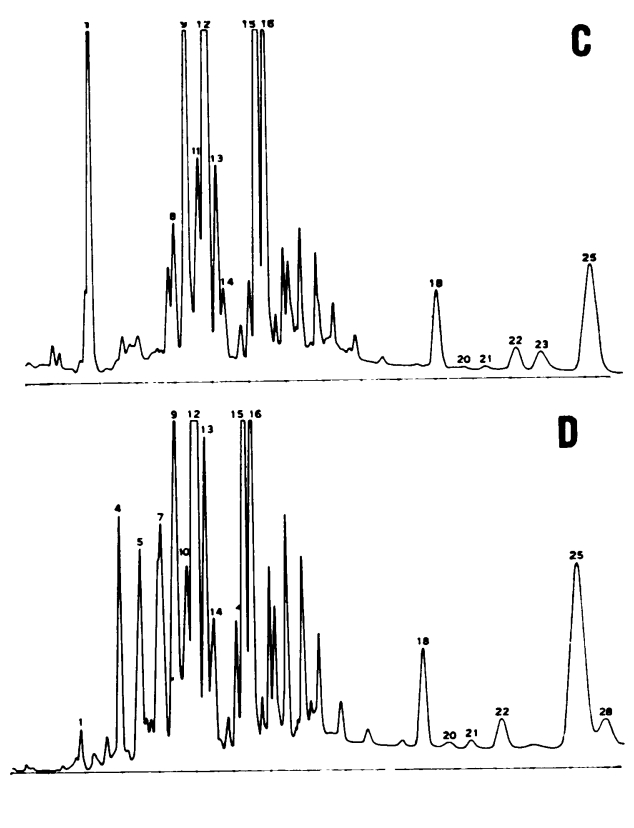

FIGURE Gas-liquid chromatograms of trimethylsilyl derivatives of whole-cell hydrolysates $(A)$ Noguchi, $(B) \mathrm{T}$. zuelzerae, $(C)$ Reiter, $(D)$ T. microdentium, $(E)$ B. vincentii.

1969b) with pure crystalline carbohydrates, only a single peak for each compound could be obtained. However, when carbohydrates are subjected to acid hydrolysis and moisture, more than one peak may occasionally be obtained for each compound. The occurrence of more than one peak for some carbohydrates in the presence of acids, moisture, and salts has been reported to be due to anomerization (Sweeley Bentley,Makita, and Wells, 1963). In the present study no attempt was made to identify the individual peaks in chromatograms; instead, we compared the overall TMS profile to evaluate this procedure as a possible technique to differentiate the cultivable treponemes. Any differences observed reflect differences in chemical composition.

Since antigenicity of treponemes has been reported to be due to their polysaccharide fractions (Christiansen, 1960, 1962), it is reasonable to speculate that 
differences in polysaccharide fractions of various treponemes may be reflected in the monosaccharides and amino sugars obtained from the hydrolysis of the whole cells. The experimental procedures and reagents used here to form TMS derivatives are for sugars and amino sugars. Thus, many of the principal peaks in the chromatograms of TMS profiles are probably due to sugars and amino sugars. The presence of carbohydrates and amino sugars in Reiter treponeme has been reported (Nell and Hardy, 1966).

It is interesting to compare serological groupings of treponemes with the grouping obtained by TMS profile. With the present work it was possible to divide thirteen strains into five groups. The TMS profile of each group was distinctly different from these of the other groups.

Serological groupings of various treponemes had been reported by some workers. Meyer and Hunter (1967) studied the antigenic relationship of fourteen treponemes by immunofluorescence. They reasoned that because of cross-reactivity with the unabsorbed conjugates there must be some common antigenic factors. In our study we found seven peaks which were common to all strains. These peaks comprise from 60 to 75 per cent. of the area of the principal peaks in the thirteen treponemes tested.

Group I contained Reiter, English Reiter, Kazan, and Kazan numbers 2, 4, 5, and 8. English Reiter and Reiter could not be separated from Kazan strains. This is in agreement with the findings of Dupouey (1963). Meyer and Hunter (1967) reported slight serological differences between Reiter and Kazan strains. However, the differences they observed were insufficient to assign the two strains to different groups. Recently Cannefax (1965) also has grouped English Reiter, Reiter, and Kazan strains into one group on the basis of common and non-common precipitins.

Group II in our study contained Nichols, Noguchi, and T. refringens strains. Cannefax (1965) and Meyer and Hunter (1967) have also grouped these organisms together serologically. Our study showed that there were more similarities between Group I and Group II organisms than between any other groups.

Two other treponemes, $T$. zuelzerae and $B$. vincentii, were placed in two separate TMS groups. This was in agreement with the serological findings of Cannefax (1965) and of Meyer and Hunter (1967). The treponeme found in normal mouth flora ( $T$. microdentium) appeared to have a distinct TMS profile, and it was placed in a group by itself. This strain was not studied by previous workers serologically. The differences in TMS profiles of various treponemes probably reflect chemical differences among these organisms. Whether these chemical differences contribute to antigenicity and serological specificity of the strains remains to be determined.

\section{Summary}

Trimethylsilyl (TMS) derivatives of whole cell hydrolysates of thirteen treponemes were examined by gas-liquid chromatography. By comparing the TMS profiles, the strains were divided into five groups. Group I contained English Reiter, Reiter, and Kazan strains. Group II contained Nichols, Noguchi, and $T$. refringens. Groups III, IV, and V contained $T$. microdentium, $B$. vincentii, and $T$. zuelzerae, respectively. The results showed excellent agreement with some serological and immuno-fluorescence findings reported earlier.

We are grateful to Dr. U. S. G. Kuhn, III and Dr. L. C. Norins for their suggestions in preparation of the manuscript, and to Mr. A. W. Hanson for technical assistance.

\section{References}

Cannefax, G. R. (1965) Dr. P.H. Thesis, University of North Carolina, Chapel Hill, U.S.A.

Christiansen, A. H. (1960) Acta path. microbiol. scand., 50, 106 (1962) Ibid., 56, 166

Cohen, P. G., Moss, C. W., and Farshtchi, D. (1970) Brit. F. vener. Dis., 46, 10

DuPOuEY, P. (1963). Ann. Inst. Pasteur, 105, 949

FarshtChI, D., and Moss, C. W. (1969a) Appl. Microbiol., 17, 262

,-- (1969b) f. Chromatogr., 42, 108

Goldman, J. N., and GIRARD, K. F. (1968) Arch. Ophthal. (Chicago), 79, 716

Hanson, A. W., and Cannefax, G. R. (1964) f. Bact., 88, 811

MeYer, P. E., and Hunter, E. F. (1967) Ibid., 93, 784

NelL, E. E., and HARDY, P. H. (1966) Immunochemistry, 3, 233

SMIth, J. L., and Israel, C. W. (1967) f. Amer. med. Ass., 199, 980

Sweeley, C. C., Bentley, R., Makita, M., and Wells, W. W. (1963). F. Amer. chem. Soc. 85, 2497

Caractérisation des tréponèmes par chromatographie gazeuse

SOMMAIRE

Les dérivés triméthysilysés (T.M.S.) de corps cellulaires entiers de 13 tréponèmes furent examinés en chromatographie gaz-liquide. La comparaison des profils T.M.S. permit de diviser les souches en cinq groupes. Le groupe I comprend les souches Reiter anglaise, Reiter et Kazan. Le groupe II comprend Nichols, Noguchi et $T$. refringens. Les groupes III, IV et V comprennent respectivement $T$. microdentium, $B$. vincentii et $T$. zuelzerae. Les résultats se montrèrent en excellent accord avec quelques recherches de sérologie et d'immunofluorescence publiés antérieurement. 